\title{
BIOCHEMICAL AND HISTOPATHOLOGICAL STUDIES ON VISCERAL GOUT IN LAYERS WITH TRIAL OF TREATMENT
}

\author{
* Abdalla, O.E. and **Ibtisam M.G. El-Din \\ * Dept. of Pharma. ** Dept. of Path. \& Clin. Path. \\ Animal Health Research Institute Zagazig. Egypt.
}

\begin{abstract}
A commercial 35 week old layer flock located in Salhia city Sharkia governorate suffered from drop in egg production, increased water consumption, diarrhea and increased mortality rate after consuming feed misformulation contain over $5 \mathrm{~kg}$ sodium bicarbonate (SB) instead of 1-2 kg per/ton feed. Post mortem examination revealed deposition of whitish chalky material in the kidneys and coating of serous surface of abdominal organs especially liver and heart by this material. A total of one hundred layer hens were divided into four equal groups. Group 1 was obtained from healthy flock, hens received normal commercial ration and served as a control group. Hens of group (2,3 and 4) were obtained from affected flock. Group 2 received misformulated ration, group 3 received corrected ration free from sodium bicarbonate and group 4 received corrected ration with addition of allopurinol at a dose level $40 \mathrm{mg} / \mathrm{Kg}$. $\mathrm{b}$. wt and the samples were taken at the beginning of the experiment and at two and three weeks later. The hematological parameters RBCs count, $\mathrm{Hb}$ concentration and PCV of affected hens were significantly increased compared with healthy ones, moreover, blood $\mathrm{pH}$ in affected hens shifted toward the alkaline side. Serum levels of uric acid, total proteins and sodium were significantly increased while potassium level and chloride were relatively decreased.Microscopic examination revealed severe renal changes in highly affected hens, these changes included coagulative necrosis and renal casts in the lumen of renal tubules. The heart showed zenkers degeneration of cardiac muscle fibers and edema.
\end{abstract}


Correction of ration improves partially the measured parameters whereas addition of allopurinol with correction of ration normalizes the examined parameters. It was concluded that correction of ration with addition of allopurinol. Leads to normalization of serum uric acid and others examined parameters in laying hen.

\section{INTRODUCTION}

The kidney in bird can be affected by a number of specific diseases and disorders. One of the important disorders associated with kidney damage is gout. Avian gout is a metabolic condition in which kidney function has decreased to the point where uric acid or urate accumulates in soft tissues of various organs in the body. There are two forms of avian gout (visceral and articular). Visceral gout present if the urates are deposited in the viscera and articular gout if the urates are deposited around the joint (Saif et al., 2003).

Visceral gout cause production loses and death in turkey (Tang et al; 2005), laying and broiler chickens (Rahman and Samad 2004), geese (Palya et al; 2004), guinea fowl (Cooper et al; 1996) and quail (Das et al; 1992).

In birds, uric acid is the end product of nitrogen metabolism. It is converted in mammals to less harmful substances with the help of enzyme uricase. This enzyme is absent in birds, Hence uric acid is the final excretory product (Osbaldiston 1968). Uric acid is produced mainly in liver and excreted by tubular excretion of the kidney (Harison and Harison 1986). High blood level of uric acid favor its precipitation in kidneys leading to tubular damage that cause hyperuricemia which is characterized by obstruction of the ureter and its branches (Mubarak and Sharkawy 1999). 
In gout, blood levels of uric acid can reach $44 \mathrm{mg} / 100 \mathrm{ml}$ as compared to $5-7 \mathrm{mg} / 100 \mathrm{ml}$ in normal birds (Harison and Harison 1986). Outbreak of visceral gout in poultry occurs due to multietiological factories; dietary causes as excessive uses of sodium in water and feed (Mubarak, 2004); excess of protein more than 30-40\% in feed (Tang et al; 2005); excess dietary calcium more than $3 \%$ with low available phosphorous less than $0.4 \%$ (Mendez et al 2001) and prolonged vitamin A deficiency (Siller, 1981) another causes may be mycotoxins such as oosporein (Pegram and Wyatt 1981). Also infectious disease as infectious bronchitis (Kang et al; 1999).

There is a little literature about treatment of visceral gout in birds. Dietary acidification with potassium chloride or methionine may be benefit for decreasing kidney lesions (Saif et al; 2003). Use of electrolytes or diuretics through water may assist in controlling mortality caused by gout (Upendra 1991). Medicinal plants play an important role for controlling mortality caused by gout (Chatterjee and Misra 2004). Also drugs, which lower plasma uric acid levels, can be used for treatment of visceral gout; these drugs can be classified according to their mode of action as uric acid inhibitors (Allopurinol and Tisopurine); uric acid execrators (Probenecid, Benzbromarone) and uric acid lyser (Urate- Oxidase) (Pawlotsky 1994).

In the present study, biochemical and histopathological changes in laying hens suffering from visceral gout caused by salt poisoning were investigated. And trial for correction of side effects of gout by allopurinol was done.

\section{MATERIALS AND METHODS}

Two layers flocks in Salhia city, Sharkia province, each contain six thousand birds of 35 week age with average body weight $1.75 \mathrm{~kg}$ were used. 
During routine observation of the farms, there is drop in egg production, increased water consumption, diarrhea and increased daily mortality (15 bird/day) in one farm of them. Post mortem examination showed that all dead birds were affected by visceral gout. From a case history about composition of ration, it is clear that the flock was fed on ration erroneously formulated to contain sodium bicarbonate (SB) over $5 \mathrm{Kg} /$ Ton instead of $1-2 \mathrm{~kg} / \mathrm{ton}$.This ration called (Ration II). Ten highly affected hens were sacrificed to confirm lesions specific for visceral gout. Another farm was fed on normal commercial layer ration contain 1 $\mathrm{kg}$ SB /ton (Ration I). The healthy condition, mortality rate and its production was normal.

Drug: Allopurinol (allopurinol 300) ${ }^{\mathrm{R}}$ produced by EIPICO; Egyptian Int. pharmaceutical industries co. $10^{\text {th }}$ of Ramadan city A.R.E.

It was added to feed at a dose level $40 \mathrm{mg} / \mathrm{kg}$ b.wt according to Melvin etal; (2002).

Rations: There are four types of ration were used in our experiment.

Ration I: is normal commercial layer ration containing one $\mathrm{kg}$ of SB / ton.

Ration II: is layer ration containing $5 \mathrm{~kg} \mathrm{SB} /$ ton (misformulated ration).

Ration III: is commercial layer ration free from SB (corrected ration).

Ration IV: is commercial layer ration free from SB and contain allopurinol at a dose level $40 \mathrm{mg} / \mathrm{kg}$. b. wt.

\section{1-Experimental design:-}

One hundred laying hens were used for this study, 25 of them were obtained from healthy flock and 75 from affected flock with visceral gout. All birds were divided into four equal groups. 
$\overline{\mathbf{1}^{\text {St }} \text { group: served as healthy control, fed on ration I contain } 1 \mathrm{Kg} \mathrm{SB} / \text { ton. }}$

$2^{\text {nd }}$ group: served as affected hens fed on ration II contain $5 \mathrm{Kg}$ SB/Ton.

$\mathbf{3}^{\text {rd }}$ group: served as affected hens fed on ration III free from SB.

$4^{\text {th }}$ group: served as affected hens fed on ration IV free from SB and contain allopurinol.

Each bird received about $120 \mathrm{gm}$ feed/day. Water ad-libitum was supplied to all groups. The experimental period continue for 3 weeks.

\section{2- Blood samples:-}

Were obtained from wing vein from 5 birds of each group at three different durations. $1^{\text {St }}$ at the beginning of the experiment $2^{\text {nd }}$ and $3^{\text {rd }}$ after two and three weeks from the beginning of the experiment respectively.

\section{3- Hematological and biochemical studies: -}

Two blood samples were collected from each bird of each group. The first sample was collected on sodium salt of EDTA for hematological studies, RBCs counts $\mathrm{Hb}$ concentration and PCV were estimated according to the method described Jain (1986), blood PH was determined using Whatman indicator papers. The second sample was used for serum separation, serum samples were used for determination of serum uric acid (Trinder; 1969). Serum total protein (Doumas and Biggs 1972), serum sodium and potassium measured by flam photometer (Bauer; 1982), serum chloride (Felid Kamb, 1974).

\section{4- Histopathological examinations: -}

Tissue specimens from kidneys and heart of sacrificed bird were fixed in $10 \%$ formalin, processed and stained with (H\&E) for microscopic examinations (Bancroft and Stevens, 1982).

\section{5- Statistical analysis:}

The data obtained were statistically analyzed (Tamhane and Dunlop, 2000). 


\section{RESULTS AND DISCUSSION}

Visceral gout is a metabolic disorder that results from hyperuricemia. It is characterized by precipitation of urates in kidney and on serous surfaces of abdominal organs causing loss of production and high mortality in laying hens (Riddell 1997).

Causes of visceral gout may be nutritional as excessive use of sodium bicarbonate which is added to feed to improve egg shell quality (Howes 1966 and charles et al 1972) and decreases losses due to heat stress (Branton et al 1986). The present results indicated that laying flock fed on ration misformulation contain high level of SB (over $5 \mathrm{~kg} / \mathrm{ton}$ ) results in typical lesions of visceral gout. Highly affected hens were emaciated and severely congested with subcutaneous edema, they showed white chalk-like deposits covering the surface of various abdominal organs as well as the heart sac (Fig. 1). Kidneys were pale with irregular and excessive enlargement of lobules. Ureters were distended with urates (Fig. 2). These observations are mimic with those described by (Davison \& Wideman 1992) and (Riddell1997) in commercial layers spontaneously intoxicated by sodium bicarbonate.

Concerning the hematological parameters (Table1):- There was a significant $(\mathrm{P} \leq 0.01)$ increase in hemoglobin concentration, RBCs counts and packed cell volume of affected layer bird compared with the healthy ones. The significant increase in the hematological parameters may be due to diarrhea, ascitis and dehydration of the affected bird (Sander et al 1998) due to toxicity of sodium sesquicarbonate toxicity in broiler chickens.

These results agree with those obtained by Mirsalimi \& Julian (1993) in broiler Mubarak \& Sharkawy (1998) in laying pullets and Sahar \& Kawkab (2004) in broilers. 
Blood PH in the affected birds was shifted toward the alkaline side. This may be due to metabolic alkalosis created by bicarbonate overload in the affected birds.

Similar results were obtained by Bottje and Harrison (1985b), Mubarak and Sharkawy (1998) and Squires and julian (2001).

In this study correction the ration improves partially the hematological variance whereas use of allopurional with the corrected ration normalizes the examined hematological parameters.

Concerning the biochemical parameters (Table2): serum uric acid showed highly significant increase $(\mathrm{P} \leq 0.001)$ in the affected bird compared to the healthy ones.

Hyperuricaemia is related to breakdown, and turnover of nucleoprotein resulting in overproduction of acid, which is accelerated in the presence of renal damage, that results in diminished excretion by renal tubules (Brown, 1996) both mechanisms will result in Hyperuricaemia.

Hyperuricaemia is an obvious manifestation of gout (Baur and krane, 1964). Similar result was obtained by Mubarak and sharkawy (1998), and Sahar and kawkab (2004) in laying pullets and broiler due to sodium bicarbonate toxicity.

This study revealed highly significant increase $(\mathrm{P} \leq 0.001)$ in sodium level, whereas potassium and chloride were significantly decreased $(\mathrm{P} \leq 0.01)$ in the affected bird compared with the healthy control (Tab 2).

The increased sodium levels in the affected layers may be due to high sodium intake (Tietz et al 1998) and inability of the birds to excrete it (Riddell, 1997). 
In this study the hypernatraemia was associated by hypokalemia. This may be due to strong relation between sodium and potassium as $\mathrm{k}^{+}$ is essential for extrusion of $\mathrm{Na}^{+}$from tissue cell (Cogan, 1991; and Tohda, 1994). In this study the decreased serum levels of $\mathrm{K}^{+}$and cl may be due to increased excretion of these elements due to renal dysfunction and loss of these elements in the watery dropping of the affected bird (Mubarak and Sharkawy, 1998).

Similar changes of blood parameters including metabolic alkalosis, hypernatremia, hypokalemia and hypochloremia were reported in commercial layers exposed to sodium bicarbonate (SB) toxicity (Davison \& Wideman, 1992). Also other animals and even human beings exposed to SB toxicity showed similar changes of blood chemistry (Thomas \& Stone 1994; Rivas et al; 1997). This agree with that obtained by Sahar and Kawkab (2004) and EJaz et al (2005) in broilers.

The present study revealed highly significant increase $(\mathrm{P} \leq 0.001)$ in total protein in the affected layers bird compared with the healthy control, this increase may be due to fluid losses by diarrhea and dehydration due to sodium bicarbonate toxicity.

Similar results were obtained by Mert (1991) in laying and broiler chickens' gout, and Sander et al (1998) due to sodium sesquicarbonate toxicity in broiler chickens.

The changes in the biochemical parameters were confirmed by histopathological changes in the kidney and heart of affected layers. The kidney of affected layers showed coagulative necrosis and renal casts in the lumen of renal tubules (Fig. 3). Other cases showed focal aggregation of mononuclear cells and few fibroblasts among necrotic renal tubules (Fig. 4). 
The heart of affected layers showed hyaline degeneration, necrosis and destruction of muscle fibers, in addition to edema and round cells infiltration among the degenerated muscle fibers (Fig. 5). Other cases revealed zenkers degeneration of cardiac muscle fibers and edema with few leuckocytic cells infiltration (Fig.6).

Similar results were obtained by Mubarak and Sharkawy (1998), and Mubarak (2004) due to toxicity induced by sodium bicarbonate.

Correction of the ration improves all examined biochemical parameters. Normalization of serum uric acid and other examined biochemical parameters achieved by dietary regiment with additional allopurinol.

Allopurinol is the powerful inhibitor of xanthine oxidase enzyme responsible for the oxidation of xanthine and hypoxanthine to uric acid and urate formation. It reduces urates and uric acid concentration in both body fluids and urine and reduces risk of renal impairment (Pawlotsky 1994). Similar results were obtained by van. Doornum and Ryan (2000) who stated that allopurinol is the drug of choice for urate lowering therapy in the presence of renal impairment, also Klandrof et al (2001) and Melvin et al (2002) stated that allopurinol with a dose level 40 or 50 $\mathrm{mg} / \mathrm{kg}$. B.wt. for 21 days by fed rout can lower plasma uric acid. Akkasilpa et al (2004) reported that the allopurinol is superior in hyperuricemic patients.

This improvement is confirmed by the improve in the pathology of the kidneys and heart. The kidney of treated layers showed mild degenerative changes in renal tubules (Fig. 7). The heart of treated layers showed mild congestion of cardiac blood vessels (Fig.8).

It was concluded that correction of ration with addition of allopurinol. Leads to normalization of serum uric acid and others examined parameters in laying hen. 
جدول بالعرض (1) 


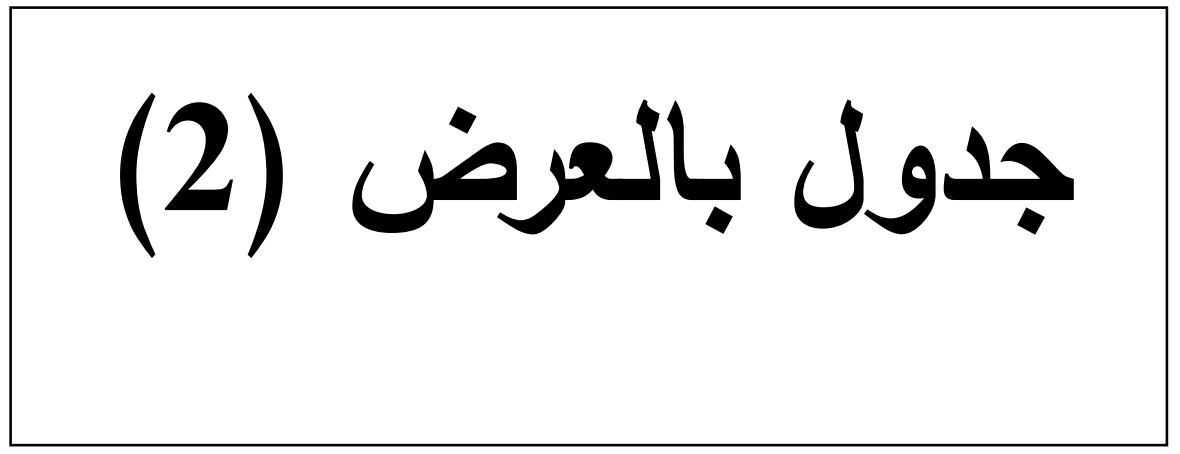




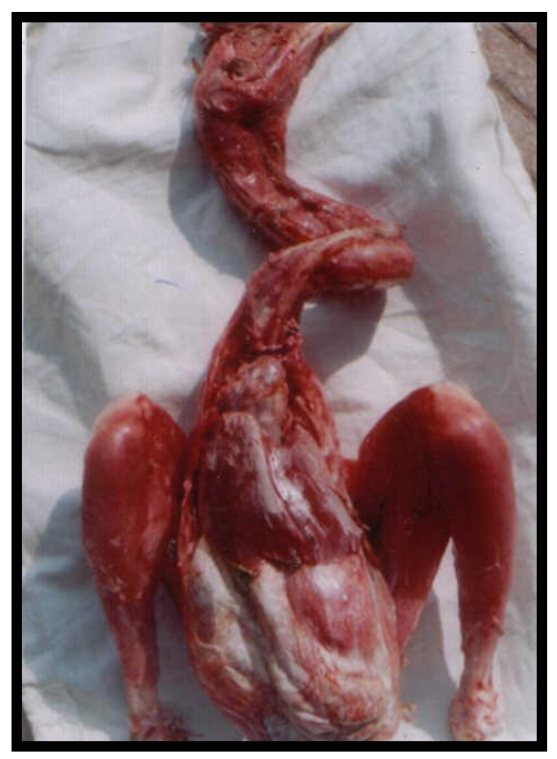

(Fig. 1): affected layers showing white chalk-like deposits covering the surface of various abdominal organs as well as the heart sac.

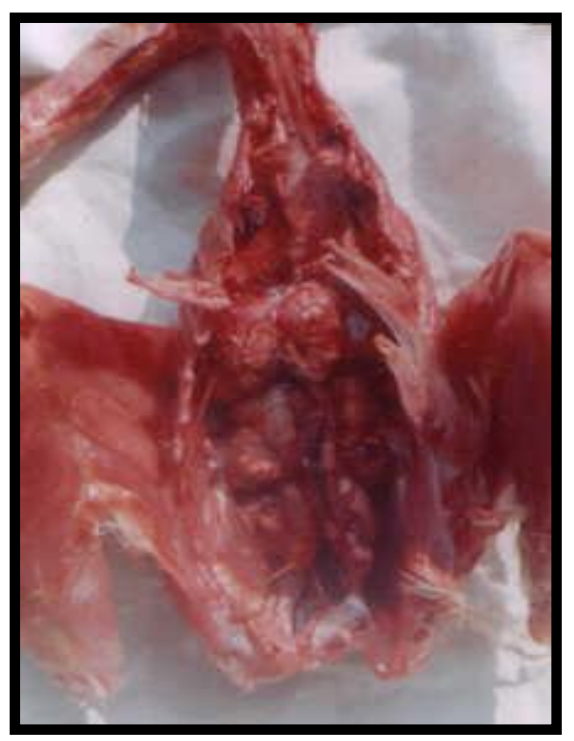

(Fig. 2): Kidneys of affected layers showing pale irregular and excessive enlargement of lobules, ureters were distended with urates 


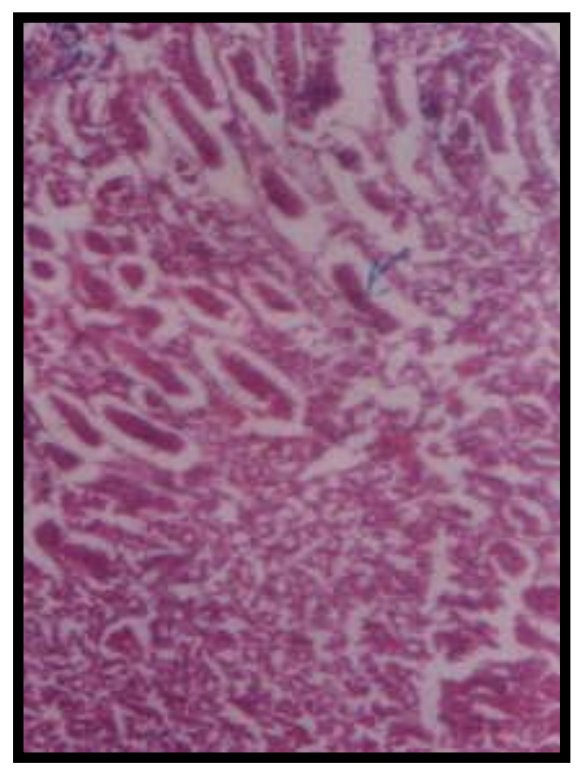

(Fig. 3): The kidney of affected layers showing coagulative necrosis and renal casts in the lumen of renal tubules(H\&E X 300)

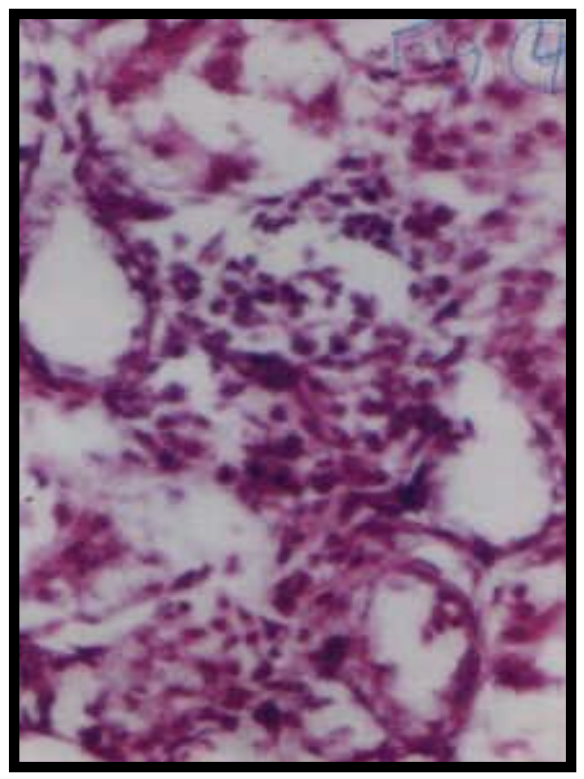

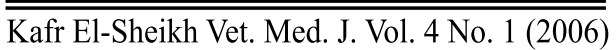


(Fig. 4): The kidney of affected layers showing focal aggregation of mononuclear cells and few fibroblasts among necrotic renal tubules(H\&E X 1200)

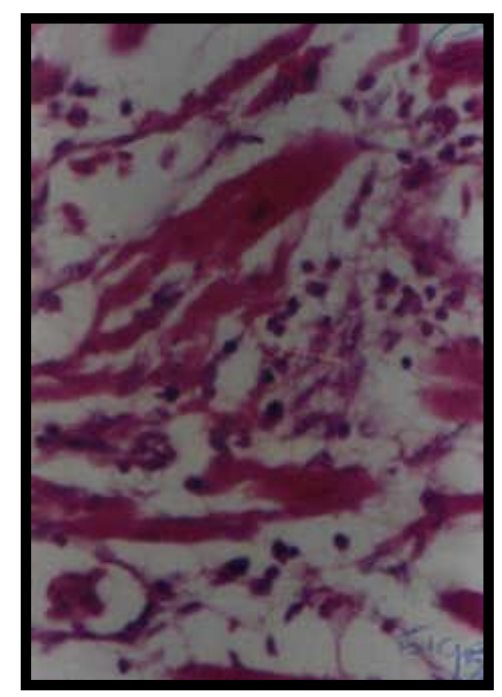

(Fig. 5):The heart of affected layers showing hyaline degeneration, zenkers necrosis and destruction of muscle fibers, edema and round cells infiltration among the degenerated muscle fibers (H\&E X 1200)

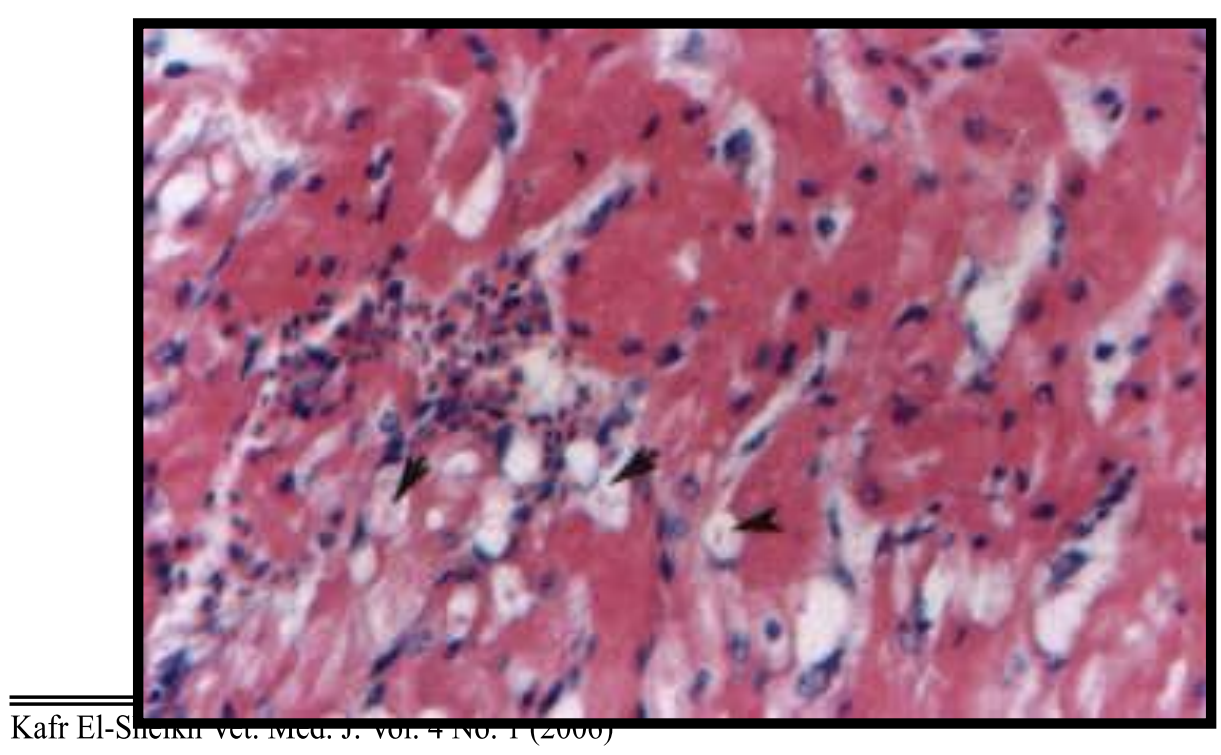


(Fig.6): The heart of affected layers showing. Zenkers degeneration of cardiac muscle fibers and edema with few leucocytic cells infiltration (H\&E X 300).

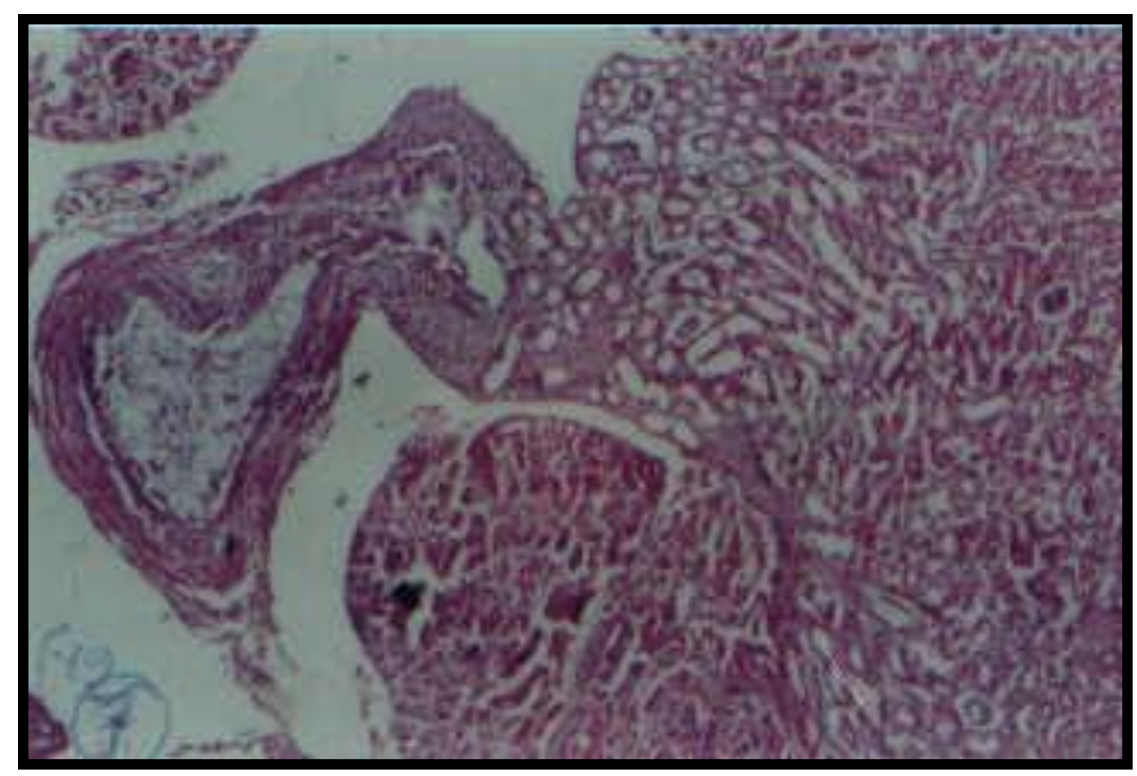

(Fig. 7): The kidney of treated layers showing mild degenerative changes in renal tubules (H\&E X 120).

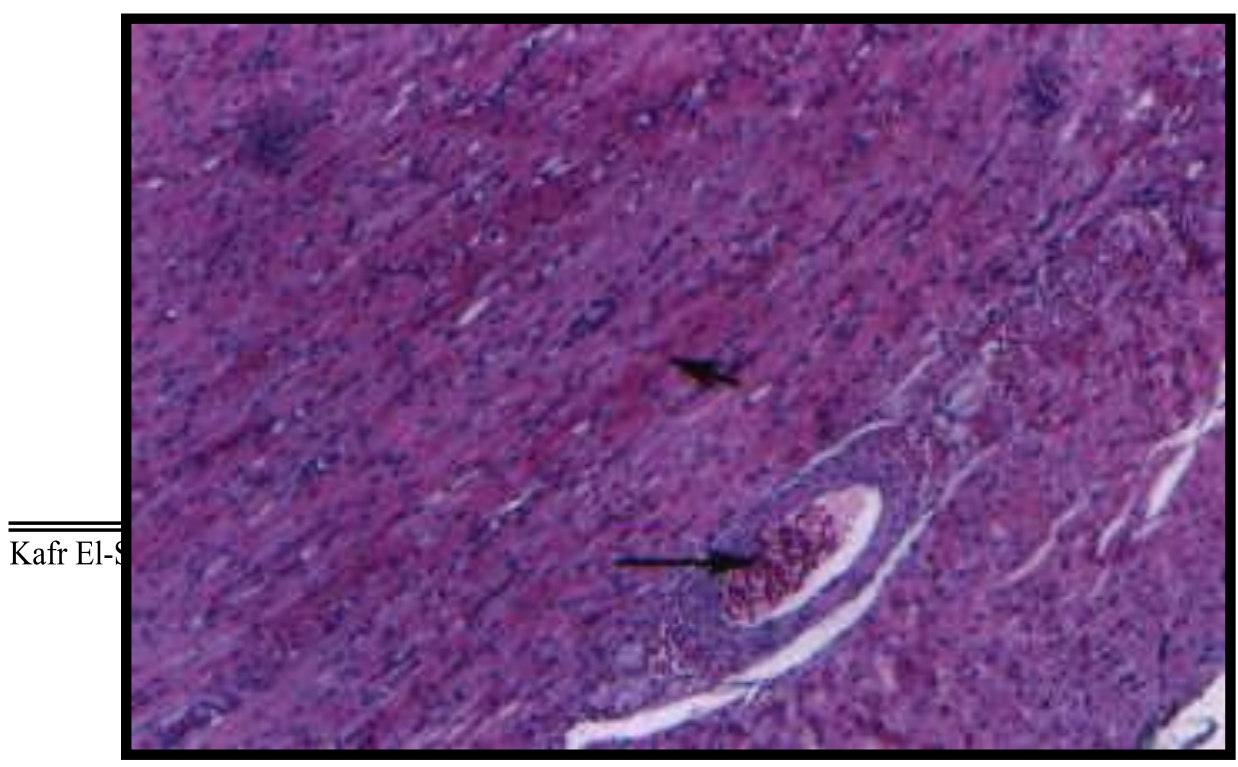


(Fig.8): The heart of treated layers showing mild congestion of cardiac blood vessels (H\&E X 120). 


\section{ACKNOWLEDGEMENT}

the authors thank dr. ansia m. HANFY professor of pathology. faculty of veterinary medicine zagazig university for her great help in the histopathological examinations.

\section{REFERENCE}

- Akkasilpa S. Osiri M. Deesomchok U. and Avihigsanon Y. (2004): The efficacy of combined low dose of Allopurinol and benzbromarone compared to standard dose of Allopurinol in hyperuricemia. J.Med. Assoc. Thai. 2004 sep, 87 (9); $1087-$ 910.

- Bancroft, D. and Stevens, A. (1982): Theory and practice of histological techniques, $2^{\text {nd }}$ edn, Churchill Living stone (Edinburgh, London, and Melbourne).

- Bauer,. J.D. (1982): Chemical laboratory methods, for determination of sodium and potassium. $9^{\text {th }}$. Ed., The C.M. Mosby Company, London.

- Baur, W. and Krane, S.M. (1964): gout In: Dun cans G.G. (Ed.) Disease of metabolism, detailed Methods of diagnosis and treatment. W.B. Sounders, Philadelphia, London, p.p.; 805849.

- Bottje, W.G. and Harrison P.G. (1985b): Effect of carbonated water on growth performance of cockerels subjected to constant and cyclic heat stress temperature. Poultry Sci. 64: 1285-1292.

- Branton, S.L. Reece, F.N. and Deaton, J.W. (1986): Use of ammonium chloride and sodium bicarbanate in acute heat exposure of broilers. Poultry Science, 65, 165- 1665. 
- Brown T.P. (1996): Urinary system. In: Avian Histopathology C. Riddell (Ed), $2^{\text {nd }}$ Edn. Pp 167-181 American Association of Avian pathologists.

- Charles, O.W, Clark, R. and Huston, T.M. (1972): The effect of calcium source, sodium bicarbonate and temperature on egg shell quality. Poultry Science, 51, 1793.

- Chatterjee, S; and Misra, S.K (2004): Efficacy of herbal Nephtone for prevention and treatment of gout in commercial broilers. Live stock international 2004; 8(6): 11-13.

- Cogan, M.G. (1991): Fluid and Electrolytes:- Physiology and Pathophysiology. Pp. 1-304. Prentice-Hall, London.

- Cooper, J. E; Max, R.A and Mbassa, G.K (1996): Health studies on a group of captive helmeted guinea fowl(Numida meleagris)in Tanzania. Avian. Path. 1996; 25(1): 135-145.

- Das, A; Chakrabarti, A. and Basak, D.K (1992): Visceral gout in Japanese quail. Indian. Vet. J 1992: 69(2): 167-168.

- Davison, S. and Wideman, R.F. (1992): Excess sodium bicarbonate in the diet and its effect on leghorn chickens. British Poultry Science, 33, 859-870.

- Doumas B.T. and Biggs H.G. (1972): Standard methods of clinical chemistry. Vol. 7, Academic Press, New York.

- EJaz,S,Kim B.S.;and Lim C.W.(2005): Gout induced by intoxication of sodium bicarbonate in korean native broilers. Drug chem. Toxicol 28 (2): 245-61.

- Field Kamb., C.S. (1974): Calorimetric determination of chloride. Z. Klin. Chem. Klin. Biochem. 12: 146-150.

- Harrison, G.J. and Harrison, L.R. (1986): Cited in clinical Avian Medicine and surgery.W.B.Sounders Company Philadelphia, London, Toronto P. 193-201. 
- Howes, J.R. (1966): Egg shell quality as affected by the addition of bicarbonate to the feed and water. Poultry Science, 45, 1092-1093.

- Jain, N.C. (1986): "Schalm's veterinary hematology" $4^{\text {th }}$ Ed. P.P. 55-96, Lee and Febiger Philadelphia, U.S.A.

- Kang. K; Mo. In pil; Kwon. Y and Kany. M (1999): Pathological evaluation of renal changes induced by multiple nephropathogenic factors in SPF chickens. Korean- J. of Vet. Res. 1999: 39 (6): 1126-1140.

- Klandorf, H., Rathore D.S, Shi, X. and Iqbal M. (2001): Accelerated tissue aging and increased oxidative stress in broiler chickens fed allopurinol. Comp. Biochem. Physiol. C. pharamcol. Toxicol. Endocr-inol 129: 93-104.

- Melvin, F.; Knox Van, D. and Hillar, K (2002): Manipulation of plasma uric acid in broiler chicks and its effect on leukocyte oxidative activity. Am. J. of physiol. Regul integra comp physiol 282: 791-796 (2002).

- Mendez. V; Alfonso, $R$ and Peralta, $M$ (2001): Report of visceral gout in white leghorn hens. Revista-cubana- deCiencia- Avicola- 2001; 25 (1) 23-28.

- Mert N. (1991): A biochemical investigation on chicken gout observed in the Marnava region in Turkey. Edv. Exp. Med. Biol. 309A 251-4.

- Mirsalimi, S.M. and Julian, R.J (1993): Effect of excess sodium bicarbonate on the blood volume and erythrocyte deformatily of broiler chickens. Avian Pathology, 22, 495-507.

- Mubarak. M (2004): Histopathology of toxicity induced in broiler chickens by excess sodium compounds. J. of Biological Sci. 4(4): 553-558. 
- Mubarak, M. and Sharkawy A.A (1999): Toxopathology of gout induced in laying pullets by sodium bicarbonate toxicity. Environ Toxicol Pharmacol. 7: 227-236.

- Mubarak, M. and Sharkawy, A.A (1998): Pathology and toxicology of gout induced in laying pullets by sodium bicarbonate toxicity -Egypt. J. Comp Path. And Clinic. Path. 11 No.2: 199- 219.

- Osbaldiston, G.W. (1968): Diuresis and uric acid excretion in fowl. Vet. Clin. Path. 2: 235.

- Palya, V. Ivanics, E; Glavits, R. and Dan. A (2004): Epizootic occurrence of hemorrhagic nephritis virus infection of geese. Avian- Path. 33(2): 244-250.

- Pawlotsky Y. (1994): Hyperuricemia and gout: therapeutic indication. Rev. prat. 1994 Jan 15: 44(2): 206- 209.

- Pegram R.A.and Wyatt R.D.(1981): Avian gout caused by oosporein, a mycotoxin produced by caetomium trilatenle pouit. Sci 60: 2429- 2440.

- Rahman, M.A and Samad, M.A (2004): Important systemic and miscellaneous diseases associated with morbidity and mortality in commercial poultry in Bangladesh. Bangladesh. J. of Vet. Med. 2004; 2(2): 91-98.

- Riddell,C.(1997): Developmental, Metabolic and other non infectious disorders. In: Diseases of poultry. B. W. Calnek, H. J. Barnes, C.W. Beard, L.R. Mc Dougald, Y. M. Said (Eds) ${ }^{10 \text { th }}$ edn. Pp. 913- 950 Iowa State University Press, Ames.

- Rivas, L. J. Hincheliff, K.W. Kohn, C.W., Sams, R.A and chew, d.J. (1997): Effect of sod. Bicarbonate administration on blood constituents of horses. American J. of Vet. Research, 58, 658- 663. 
- Saif, Y.M; H.J. Barnes; J.R.Glisson, Fadly A.M. Mc Dougld L.R. and Swayne D.E. (2003): Sitedia Disease of poultry $11^{\text {th }}$ ed. PP. 1085-1086 American Association of Avian Pathologist Iowa State Press.

- Sahar. A. and Kawkab. A.A. (2004): pathology of gout induced by sodium bicarbonate toxicity in broilers. J. Egypt. Vet. Med. Assoc. 64 No.1:125-136.

- Sander J.E Savage S. I and Rowland G.n. (1998): Sodium sesquicar-bonate Toxicity in broiler chickens. Avian Disease Jan- Mar, 42(1) 215-8.

- Siller, W.G (1981): Renal pathology of the fowl-a review. Avian pathol. 10: 187-262.

- Squires E.J., and Julian Rj. (2001): The effect of dietary chloride and bicarbonate on blood $\mathrm{PH}$, hematological variables, pulmonary hypertension and ascitis in broiler chickens. Br. Poult. Sci. May, 42 (2): 207-12.

- Tamhane, A.C. and Dunlap D.D (2000): Statistics and Data analysis from elementary to intermediate upper saddle River, USA.

- Tang-J; Huang,K.; Guo, X. and Gao, J(2005): Experimental studies on avian gout induced by dietary high calcium and high protein. Chinese. J. of Vet. Sci 2005: 25 (2): 203- 205.

- Thomas, S.H. and Stone C.K. (1994): Acute toxicity from backing soda ingestion. American J. of Emergency Medicine 12, 57-59.

- Tietz N.W.; Siggaard A.O.; and praden El.I. (1998): Acid base balance and acid-base disorders. In: Tietz text book of clinical chemistry, $2^{\text {nd }}$ Ed. B.W. Saunders, Pheladelphia, London, Toranto, 1420- 1448. 
- Tohda, K.: (1994): Sod. In: hand book on metals in Clinical and analytical chemistry. H.G. seiler, A. Sigel, H. Sigel (Eds.) pp. 531- 534. Mercel Dekker inc Ny, Basel, Hong kong.

- Trinder, P. (1969): Enzymatic calorimetric method for estimation of uric acid. Ann. Clin. Biochem. 6: 24.

- Upendra, H.A (1991): Clinical drug trial in broiler visceral gout. Poultry-Adviser 1991; 24 (11): 45-47.

- Van Doornum S, and Ryan P, F. (2000): Clinical manifestation of gout and their management. Med. J. Aust. 2000 May 15: 172 (10): 493-497.

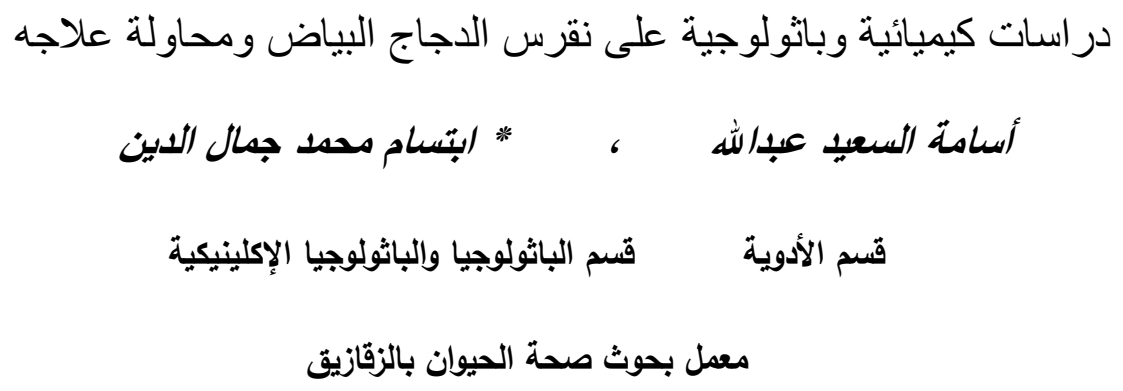

تم إجراء هذا البحث على مزارع دجاج بياض عمره 35 أسبوع بمدينة الصـالحية- محافظـة الثرقية، حيث وجد أحد المزارع به انخفاض ملحوظ بالإنتاج اليومي للبيض مع زيادة في استهلاك معدل مياه الثرب وإسهال مائي بالإضـافة إلى ارتفاع معدل النافق اليومي. وبإجراء الصفة التشريحية تبين وجود نرسيبات طباشـيرية على الأعضـاء الداخليـة للدجاج المصـاب وتضخم شديد بالحالبين والكلى وبدارسة أسباب هذه الحالة اتضح أن هناك خطأ في تركيبه العلف حيث تضاف بيكربونات الصوديوم بمعدل أكثر من 5 ك/طن علف و بقياس حامض البوليك فى السيرم وجد أنه مرتفع إرتفاعا ملحوظا. مما يوضح إصابة القطيع بالنقرس الحشوي. 
وقد أجريت هذه التجربـة على مائة دجاجة بياض عمر 35 أسبوع (25 دجاجـة سليمة و 75 دجاجة مصابة) وقسمت إلى 4 مجاميع منساوية في أققاص منفصلة على النحو الثالي. المجموعة الأولى: دجاج سليم يتغذى على عليقة بياض تحتوي على 1 ك بيكربونات الصوديوم/طن (ضابطة).

المجموعة الثانية: دجاج مصاب يتغذى على عليقة بياض تحتوي على 5ك بيكروبونات الصوديوم/

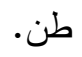

المجموعة الثالثة: دجاج مصاب بتغذى على عليقة بياض خالية من بيكربونات الصوديوم. المجموعة الرابعة: دجاج مصاب يتغذى على عليقة بياض خالية من بيكربونات الصوديوم وتحتوي على الوبيورنول بمعدل 40 مجم/ كجم من وزن الطائر.

استمر العلاج والملاحظة لددة 3 أسابيع ونم أخذ عينات دم للفحص الكيميائي والباثولوجي في بداية التجربة وبعد أسبوعين وثلاثة أسابيع واتضح من النتائج مايلى:-

زيادة معنوية فى عدد كرات الدم الحمراء ونسبة هيموجلوبين الدم و حجم الخلايا الدضغوطة

بالدجاج المصاب مقارنةً بالدجاج السليم كما أن درجة الحموضـة PH اتجهت نحو القلويـة. كما وجد خلل في وظائف الكلى حيث اقترن بارتفاع حامض البوليك والبروتين الكلى والصسوديوم في الدجاج الدصاب مقارنة بالدجاج السليم. وبتغير العليقة للاجاج الدصاب بعليقة خالية من بيكروبونات الصوديوم حدث تحسن جزئي في القياسات السابقة وعند إضافة عقار ألوبيورنول مع تغير العليقة حدث تحسن

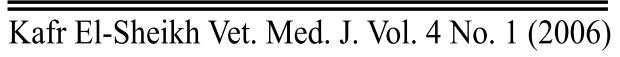


كامل في القياسـات السابقة وخاصـة انخفاض معنوي فى حامض البوليك فـى الدجاج المعالج مقارنـة بالاجاج المصاب.

مما سبق يتضح إمكانية استعمال عقار الوبيورنول بجرعة 40 مجم/ كجم وزن الطائر كعلاج للاجاج المصاب بالنقرس الناتج عن التسمح بأملاح بيكربونات الصوديوم. 